\title{
SIN Í AN CHEIST A CHUIREAS ORM FÉIN: MODERN IRISH PRESENTATIVE CONSTRUCTIONS ${ }^{1}$
}

\author{
ORIT ESHEL
}

\author{
Philipps-Universität Marburg
}

\begin{abstract}
This article surveys two types of Modern Irish presentative constructions. These constructions open with a presentative element and introduce an NP (entity) or a nexus (a situation or an event involving an entity) into the discourse. I describe the constructions' poetic functions in literary narratives by Pádraic Ó Conaire (1882-1928). The first type of presentative construction opens with one of the deictic-presentative elements seo 'here', sin 'there' or siud 'yonder'. The second type of presentative construction features as a presentative element of various forms of perception and cognition verbs, such as d'fheicfeá 'you'd see' and shilfeá 'you'd think'. Presentative constructions in literary narrative are used in several functions: expression of a point of view, either the narrator's or that of a character, scene-setting, explication, and signalling boundaries in the text in varying degrees of cohesion and delimitation. The latter is also used to 'sudden effect', adding drama and speeding up story time.
\end{abstract}

Keywords: Modern Irish, narrative, presentative, sentence-focus, thetic

1 Research for this paper was supported by the Minerva Foundation. I wish to thank Asaf Bin-Nun, Malachy McKenna, Erich Poppe, Hagay Schurr and Tally Shitrit, for reading versions of this paper. I would also like to thank the anonymous reviewers for their helpful comments. 


\section{Introduction}

PRESENTATIVE constructions are used in order to turn attention to an entity or to an event or situation involving an entity. While in spoken language turning attention may be accompanied by finger pointing, the linguistic manifestation of "pointing" is a PRESENTATIVE ELEMENT as for example the French voilà or Modern Hebrew hinne. ${ }^{2}$

In Modern Irish presentative constructions, presentation of an entity is carried out by means of the construction 'presentative element + NP'. Presentation of a situation or an event involving an entity is carried out by using the construction 'presentative element + NEXUS'. The former is more abundant in dialogue and the latter in narrative texts.

As a brief initial clarification, let us consider the basic dialogic presentative construction. In this construction, there appears first one of the deicticpresentative elements: seo 'here', sin 'there' and siúd 'yonder'. Following this appears the presented entity, represented by a NP: a pronoun, Proper Name, a definite or indefinite noun, as demonstrated respectively in Table 1. Further formal features and functions of this construction are discussed in section 2 .

Table 1 Seo + NP: entity presentation

\begin{tabular}{|l|c|c|}
\hline $\begin{array}{l}\text { Presentative } \\
\text { element }\end{array}$ & Presented entity: NP & Translation \\
\hline \multirow{4}{*}{ Seo 'here' } & é & 'Here he is' \\
\cline { 2 - 3 } & é Mac Uí Fhrighil & 'Here's Mac Uí Fhrighil' \\
\cline { 2 - 3 } & cupán tae & 'Here's a cup of tea' \\
\cline { 2 - 3 } & $\begin{array}{c}\text { i an bhean atá fúm a } \\
\text { phósadh }\end{array}$ & $\begin{array}{c}\text { 'Here's the woman I intend to } \\
\text { marry' }\end{array}$ \\
\hline
\end{tabular}

I maintain that some perception and cognition verbal forms, especially in the $2^{\text {nd }}$ person singular conditional form, such as d'fheicfeá 'you'd see' and shilfeá 'you'd think', function as presentative elements. As far as I am aware, there is no description of their usage in the literature, and certainly not as presentative forms. Consider the following example:

2 See also Cohen (2014: 23): "Presentative constructions and their functions constitute a cross-linguistic category, which is found in quite a few languages [...]. The various presentative constructions in French (c'est...qu-, il y a, voilà) have been well-studied, both in terms of their analysis (Lambrecht 2000) and their functions (e.g., Rabatel 2001). Another well-known example is the Biblical Hebrew exponent (wa)hinne. The functions of these exponents may be summarized by their capability of introducing various entities into reality ("here I am") as well as into discourse ("there came a man"). In the former group are found functions such as performatives as well as various expressions of tense, and in the latter, various expressions of point of view." 
(1) Ní raibh sa seomra ach coinneal, agus d'fheicfeá dhá scáil ar an mballa bán

There was nothing in the room but a candle and you could see two shadows on the white wall

(Ó Conaire 1982: 114)

In this paper, I analyse presentative constructions, as evidenced in the literary writing of Pádraic Ó Conaire (1982-1928), with reference to Máirtín Ó Cadhain (1906-1970), both representing the literary Modern Irish of Conamara. ${ }^{3}$ I examine the narrative portions of literary fiction, in contrast to the dialogic ones, and describe the poetic functions performed by these constructions.

This study was carried out using a structural text-linguistic approach that builds and elaborates upon linguistic theories regarding mostly narrative and discourse structure. ${ }^{4}$ This study is also informed by a range of narratological works, including works in film theory and cinematography, which were helpful in furnishing necessary terminology for the description of narrative functions and especially in the understanding of three major phenomena - narratorship; manipulation of story-time; and expression of point of view, subjectivity and consciousness.

Basic Modern Irish presentation constructions of the kind seo + NP or seo + nexus have hardly been treated but in passing (for example Ó Siadhail 1989: 234-235, Shisha-Halevy 2003a: 261). A small and important contribution was made by Mahon (1984). Furthermore, there has not been any discussion of a presentation category in Modern Irish and no correlation has been made between different constructions as expressing one functional category. Unfortunately, Mahon as well as other grammarians who mention these basic constructions do not treat them in consideration of their linguistic environment, that is according to the text-type they appear in. This distinction is vital since meanings and functions are not one and the same in different environments.

3 The corpus includes Pádraic Ó Conaire's first-person narration novel Deoraíocht 'Exile' (1994 [1910]) and short stories that appeared in two anthologies: Scothscéalta (1982) and Rogha Scéalta (2008). Also included are two novellas by Máirtín Ó Cadhain that appear in Dhá scéal / Two Stories (2006).

4 The method of analysis used in this study is in principal structural, seeing the language as a system of signs, which are couples of form and function/meaning. In this method, in order to reveal the value of a linguistic entity, the corpus is scanned for seemingly similar entities called 'minimal pairs' that are compared in search for a pertinent opposition between them. A pertinent opposition is an opposition that creates a difference of meaning or function. The tools for the examination are the syntagmatic and paradigmatic axes, which are crossed at the slot of the examined entity. The examination of a large number of minimal pairs reveals what possible contents occupy a fixed syntactic slot. See Shisha-Halevy (1998: 9-15) and Cohen (2016) for a discussion of this method, as practiced in the Jerusalem school of linguistics. 
In this article, I examine presentation constructions in narrative literary texts in Modern Irish. Accordingly, the functions of the constructions have to do with the act of narration and the narrator's poetic intentions. While in this article I concentrate on basic presentation patterns featuring a presentative element, a separate article (Eshel, submitted) treats presentational constructions of the type lá breá gréine a bhi ann 'it was a nice sunny day', which is familiar as the 'abnormal sentence' (Mac Cana 1973) and which I term 'presentational cleft sentence'. These contributions on presentation constructions are a part of a comprehensive study of literary Modern Irish narrative grammar I have conducted in recent years (Eshel 2015).

In section 2, I discuss the concept of presentation and survey the two main approaches to this phenomenon. Section 3 describes presentative constructions opening with the deictic-presentative elements seo, sin and siúd. Section 4 surveys constructions opening with a perception or cognition verb.

\section{Presentation}

The term PRESENTATION refers to the act of presentation, which in face-to-face conversations often involves deictic pointing to a referent, linguistically represented by a NP (Lambrecht 1994: 39), calling attention to it and thereby introducing it into the discourse. Similarly the term PRESENTATIVE CONSTRUCTIONS refers to constructions signalling such acts. I use it specifically for constructions featuring a presentative element. ${ }^{5}$ PRESENTATIONAL refers to the function signalled by such constructions. I reserve the term PRESENTATIONAL CONSTRUCTIONS for such constructions, which do not feature a presentative element, such as presentational cleft constructions (see Eshel, submitted).

Two prominent proponents of research on the topic are Sasse on Theticity (1987, 2006) and Lambrecht on Sentence-Focus (1994, 2000 among others), who differ in regard to the categorization and motivation of such utterances. Sasse picks up the distinction of thetic and categorical assertions. Categorical assertions are those in which there is a subject and a predicate, providing information about the subject. In contrast, in thetic assertions, even when there are both a grammatical subject and predicate, they are perceived as one unit, which cannot be further distinguished into information structure units. In other words, the same contents may be packaged as categorical or thetic. Sasse (1987: 558) sees this as a discourse-pragmatic distinction:

5 PRESENTATATIVE is also used in the literature in reference to the presentative element. See for example Rabatel (2001) who discusses the French 'présentatifs' c'est, il y a, voici/voilà. 


\begin{abstract}
The thetic statement forms a unit with respect to what it contributes to the discourse at a given point. It expresses a pragmatically unanalyzed state of affairs and presents it as a piece of complex information. When I am confronted with [thetic statements], I have the whole situation present at once. Thetic statements are thus uttered at those points of the discourse when compact information is required.
\end{abstract}

At what points of the discourse is such information required? Thetic utterances are used "whenever the speaker assumes that the hearer expects unitary information to be given about the whole situation in question" (Sasse 1987: 568). A spectrum of functions and contexts require such unitary information (Sasse 2006):

- Annuntiative: announcements, headlines, exclamations, 'out of the blue' statements

- Introductive: discourse participants introduction

- Descriptive: scene setting function, for example environmental conditions presented as a background to the main story line

- Interruptive: a sudden, unexpected new situation or event that disrupts a chain of events

- Explanative: identification, explanation or elaboration on a given situation

- Connective: episode introduction signalling cohesion or shift from preceding episode, i.e. different degrees of connectivity

Sasse finds that thetic utterances are expressed in different languages by comparable constructions (2006: 300) but he does not see them as a crosslinguistic category. In contrast, Lambrecht views such utterances as a universal information-structure category and analyses them in terms of their focus scope (2000: 611).

Lambrecht (1994) distinguishes three information structure categories (the Irish examples are mine): ${ }^{6}$

i. Predicate-Focus (PF), in which only the predicate is focused, as in unmarked verbal clauses (e.g. D'OSCAIL an bhean an doras dom 'The woman OPENED the door for me');

ii. Argument-Focus (AF), in which an argument is in focus, as in the canonical cleft sentence (e.g. is AN BHEAN a d'oscail an doras dom 'it's THE WOMAN who opened the door for me');

iii. Sentence-Focus (SF), in which the focus extends over both subject and predicate (e.g. AN BHEAN A D'OSCAIL AN DORAS DOM 'THE WOMAN OPENDED THE DOOR FOR ME').

6 The example in (iii) appears in the studied corpus. Using the same contents, I constructed the other two examples according to the information structure category. 
The SF category corresponds in large part to Sasse's thetic assertions. Within this category, Lambrecht (1994: 144) discusses presentational sentences, which are "entity central" and serve to introduce an entity into the discourse, as in the English example here's a cat. The same syntax serves also event-reporting sentences, which are "event central" and necessarily involve an entity. Thus, a SF utterance can present the cat involved in an event, as in the example here comes the CAT (Lambrecht 1994: 237).

Lambrecht further uses these examples to demonstrate that the English hereconstruction performs both a SF presentational function and a PF function. On the one hand, the English construction 'here $\mathrm{X}$ ' signals presentation (Lambrecht 1994: 237). In the case of here the cat COMES or here comes the CAT, $\mathrm{X}$ is the cat coming. On the other hand, this example also shows PF-marking devices, namely, the prosody and the position of the NP. This means that in fact a predication [NP + a predicate] is presented and that a SF construction can be both presentational and predicational. This is in contrast with Sasse who claims that that while in categorical sentences something is being predicated about an entity, in thetic constructions there is no such division, but one unit that cannot be further analyzed.

My analysis of the Modern Irish constructions in question is in line with Lambrecht regarding the inner analysis of the presented elements. When only an entity, represented by an NP, is presented into the discourse, no problem is posed. When an NP involved in a situation or an event (expressed by an AdvP in the investigated construction) is presented, I find it difficult to look at the two as one unit without further divisions. This difficulty is also due to the fact that the entity referred to is often known from the ongoing text, and is pronominal and anaphoric. I therefore analyze the nominal constituent as thematic and the adverbial phrase as rhematic, between which there is a nexal relationship.

Consider seo chugam $i$ 'here she comes towards me', which appears in example (15) discussed in section 3.2 below. In this example, the deicticpresentative element seo presents an entity, represented by the pronoun $i$ 'her' and a movement expressed by the adverbial phrase chugam 'towards=me'. The pronoun refers to a character just mentioned who is therefore thematic. The adverbial phrase is rhematic (predicational) in relation to the theme.

In summary, I use the terms THEME and RHEME to refer to the entity and the situation/event respectively. NEXUS refers to the interdependent relationship between the theme and the rheme and also to the two elements together as a unit. This allows me to speak of NEXUS-PRESENTATION. Most of the constructions described in this article do just that: they present a nexus into the narrative. This presentation signals an array of functions, corresponding to those distinguished by Sasse and listed above. 


\subsection{Side note: existential statements}

Existentials are often analyzed as thetic or SF as existentiality correlates with the function of introducing an entity into the discourse (see for example Gast and Hast 2011). I do not classify existential statements as presentative, since I see the core function of presentation as turning attention and not stating existence. Turning attention to existence is however possible. This is seen in the minimal opposition between the following two examples. The first demonstrates the unmarked existential statement of the kind bhi NP ann, featuring the copula bi and the existence predicate ann with the existent represented by the NP. ${ }^{7}$ The second is a presentational cleft construction, which presents an existential statement:

(2) Nuair a bhí Alum-ba ina rí ar chrích na nAibitíneach bhí saor cloch ann agus bhí cáil mhór air ar fud na Oirthir ar fheabhas a cheardaiochta. When Alum-ba was a king on the land of Abitines, there was a sculptor and he was esteemed throughout the Orient for the excellence of his craftsmanship.

(Ó Conaire 1982: 44)

(3) Lá breá gréine a bhí ann agus bhí na sráideanna lán de dhaoine It was a nice sunny day and the streets were filled with people

(Ó Conaire 1994: 1)

I cannot discuss the functional differences in this article. Explanations of presentational cleft constructions presenting existentials are found in Eshel (submitted).

\section{Presentative elements: seo, sin, siúd}

Seo, sin and siúd are usually analysed as deictic demonstratives (Ó Baoill 2009: 188 ) or as copular forms which can be deconstructed to a copula and a pronoun: is eo, is in, is iúd (Ó Siadhail 1989: 234.) See also Mahon (1984) for different analyses of these forms. We will come back to the copular analysis in section 3.1.1 below.

$7 \quad B i$, traditionally termed 'substantive verb', is often analysed as an auxiliary verb (Ó Baoill 1994: 202) or as a verbal counterpart of the copula, which is semantically distinct from the copula - while the copula signals inherent qualities, bi signals more temporary states. Syntactically, the copula is used with nominal predicates while $b i$ with non-nominal predicates (Doyle 2001: 66-67). A different approach sees bi not as a verb but rather as a 'statal' or 'statal-existential' exponent participating in adverbial 'statal' or 'existentialstatal' patterns (Shisha-Halevy 1998: 201-204). Since I view both is and bi as exponents of the nexal link, I address both as copulas. In the case of $b i$, I refer to it as the 'copula $b i$ '. 
The only one to describe these elements as presentatives, homonymous with demonstratives, is Shisha-Halevy (2003a: 261). He defines them as deicticexistential, distinguishing between proximal seo and sin which are used in the speaker's here-and-now, and distal siúd, used when talking about a referent in the third person.

As demonstrated in Table 1 above, seo/sin/siúd present an NP: a proper name, indefinite NP and a definite NP, respectively. According to Ó Siadhail (1998: 234-235), the élitiad insertion rule operates in this construction, as in copular sentences. ${ }^{8}$ Mahon (1984: 143) notes that in some examples in his corpus the pronoun cannot be explained by the rule, i.e., there appears an "unnecessary" pronoun when the rheme is an indefinite noun. I will address this issue again in section 3.1.1 below.

"Seo é Mac Ui Fhrighil..."

"Here is Mac Uí Fhrighil..."

(Ó Conaire 1994: 120)

(5) "Seo cupán tae agus ruainne aráin ime"

Here's a cup of tea and a piece of buttered bread

(Ó Conaire 1994: 98)

(6) "Seo i an bhean atá fúm a phósadh"

"Here is the woman I intend to marry"

(Ó Conaire 1994: 119)

While seo points to nearer point in the space, sin points to a farther point in the space:

(7) 'Cé a dúirt leat go raibh mé le pósadh? Má tá, cá bhfuil an bhean?' arsa mise. 'Sin í thall i' ar sise.

"Who told you I am to marry? And if I am, where is the woman?" I said.

"That's her there" she said.

(Ó Conaire 1994: 107)

Syntactically, the presented element (also called the PRESENTATE) is an object actant of the presentative element. This can be seen by its placement, which when pronominal appears in final placement in the construction (Shisha-Halevy

8 The $e$, $i$, iad insertion rule applies to the nominal copular system, i.e, in identificatory sentences or cleft sentences, in the dialects of Munster and Connacht. According to this rule, a third person pronoun is inserted before a definite noun. The pronoun agrees in gender and number with that of the definite noun (Ó Siadhail 1989: 224). 
2003a: 261). This is also seen by the accusative form of the NP when it is pronominal, e.g. é ('him') and not the nominative sé 'he'.

Note that there is no longer a distinct accusative case in Modern Irish. However, there are two forms for the third person pronouns, e.g., $3 \mathrm{msg}$ sélé, 3 fsg si/i, 3pl siad/iad, with a similar distinction made at times in the $2 \mathrm{sg}$ tú/thú. The first of each pair is the subject form or nominative form. The second one is historically an accusative. ${ }^{9}$ Synchronically, this form is used to express a complement of a verb or to represent the theme in nominal constructions.

That the pronoun is accusative is significant since, according to Lambrecht (2001: 667), presentational constructions "exhibit one formal constant across languages: they are structures in which the subject constituent tends to bear some or all of the morphosyntactic, prosodic, or behavioral features normally found with the focal object in a corresponding [unmarked] construction."

Regarding the information status of the presentate, Mahon (1984) discusses the construction 'Demonstrative (seo/sin/siúd) + RHEME'. Another analysis of the informational status of such constructions sees the entire construction as a 'pre-nexal' pattern, presenting into the discourse an element that can then serve as a theme (Shisha-Halevy 2003a: 261f). Shisha-Halevy seems to address only the status of a NP that is inserted while Mahon seems to address both possibilities - whether a NP or a nexus are presented, they are rhematic.

I will now turn to surveying narrative presentative constructions as found in the corpus. Section 3.1 discusses a presentative construction opening with $\sin$ and presenting an NP or a nominalization. Sections 3.2 and 3.3 describe nexuspresentation constructions opening with seo or siúd respectively.

\section{1. 'Sin + NP': Textual presentation}

This section discusses a presentative construction opening with $\sin$ and presenting an NP or a nominalization, which functions to identify an aforementioned entity or clarify the nature of the preceding textual segment. I see this type of presentation as textual presentation, playing on Ribera's term text deixis. ${ }^{10}$ Since the structural analysis of this construction poses several

9 Different terms refer to this form in the literature: accusative (Wigger 2003: 257), accusative form used in all positions but subject position (Ó Baoill 2009:185-6), nonsubject pronoun (Doyle 2001: 38), object pronoun (Ronan 2011: 37) and disjunctive form (in contrast to conjunctive form), depending on whether the pronoun follows a finite verbal form or not (Ó Siadhail 1989: 339).

10 Ribera (2007: 152) defines text deixis as a reference device - mostly a demonstrative which shares the referential properties of both deixis and anaphora. Whereas pragmatic deixis and anaphora show space and time relations between the addressor and the entities referred to, textual deixis refers to entities in the metaphorical spatial text domain, and highlights the textual distance (in relation to the antecedent) and the emotional distance, 
problems, I would like to first look at some examples and discuss the narrative function signalled by the construction.

The presentative element $\sin$ refers anaphorically to a specific element or a whole textual segment. The presented NP or nominalization then provides orienting information about that element or segment: identification, classification, explanation, interpretation and so on. In this way, the narrator comments on the previous textual segment. Often this is an interpretive or explicative comment, orienting the reader. Informationally, in the wider macrosyntactical context, the construction acts as a Comment on a just-mentioned Topic:

(8) 'A mháthair,' ar sise - sin é an t-ainm thug sí ar an tseanbhean i gcónaí "Mother," she said - that is what she always called the old woman

(Ó Conaire 1982: 35)

(9) 'Cé mhéid?' ar seisean, agus sin é an chéad fhocal chuala sí uaidh riamh.

"How much?" he said, and that is the first word she had ever heard from him.

(Ó Conaire 1982: 101)

With this construction, the narrator can also frame the preceding textual segment and signal a boundary. This framing function brings us to a prominent function of presentation constructions - that of juncture, meaning the signalling of boundaries in the text in varying degrees of cohesion and disjunction. ${ }^{11}$

Ó Conaire uses this pattern in order to frame dialogues or passages representing a character's consciousness. Example (10) taken from a firstperson novel shows a switch from the I-character's thought to the I-narrator's comment regarding that thought:

(10) Céard déarfai i nGaillimh? Sin í an cheist a chuireas orm féin What will they say in Galway? That is the question I asked myself

(Ó Conaire 1994: 22)

It often seems to me that Ó Conaire had no confidence that the reader would understand that a certain passage expresses the character's thoughts so his narrator makes sure the reader is well oriented, as example (11) also demonstrates. There, free indirect discourse is followed by a presentative

with which the addressor perceives the referred-to entity.

11 On juncture in general, and specifically in Modern Welsh, see Shisha-Halevy (2003b). 
orienting comment. This example also demonstrates that the relative element $a$ opening nominalized clauses may be omitted, which is not unusual in Ó Conaire's writing: ${ }^{12}$

(11) Dá mbeadh deoch aici! Sin é shil sí. If she only had a drink! That is what she thought.

(Ó Conaire 1982: 96)

While in Ó Conaire's writing this pattern mostly opens with sin, in Ó Cadhain's writing it often opens with $b a$ shin. I will discuss this opposition in Section 3.1.1 below:

(12) Loic na fatai sa mBuaile anuraidh. Sin é a d'fhág d'uireasa seanfhataí anois í...

The potatoes in the upper pasture failed last year. That's what left her now with a lack of old potatoes...

(Ó Cadhain 2006: 17)

(13) Deireadh a máthair gurbh uabhar a bheith ag féachaint rómhinic sa scáthán. Ba shin é a níodh Liúsafar.

Her mother used to say that it was arrogant to be looking too often in the mirror. That was what Lucifer would do.

(Ó Cadhain 2006: 15)

In Ó Conaire's writing, $b a$ shin is contracted to $b$ 'in:

(14) '[... ] Ach maidir le hAlf Trott bocht' - b'in é an Fear Beag Buí - 'rinne seisean a dhicheall mé a leigheas.'

“'[...] But regarding poor Alf Trott' - that was the Yellow Little Man 'he did his best to cure me",

(Ó Conaire 1994: 94)

\subsubsection{Discussion}

The construction opens with the presentative element $\sin$ or its past-conditional tense variant $b a \operatorname{shin} / b$ 'in. For the sake of clarity, I will address both as $\sin$. Sin presents and points anpahorically to a preceding element or textual segment. The presented element is a NP, usually definite (exx. 8-10, 14), or a

12 This is also evidenced in the attributive clauses in (8) and (9). 
nominalization carried by the relative element $a$ (exx. 11-13). ${ }^{13}$ This NP is rhematic as Mahon also claims, giving the reader new orienting information regarding the preceding noun or textual segment to which sin points.

The analysis of this construction raises some issues, especially regarding the essence of the element $\sin$ and following that the characterization of the construction itself. It has been suggested that in southern dialects, seo/sin/siúd have been reanalysed as a copula: e.g. seo > (i)s eo, $\sin >(i)$ s in (Mahon 1984: 143, Ó Siadhail 1989: 234). Constructions of the type seo/sin/siúd + NP (e.g. seo fear 'here's a man'), it was claimed, have come to replace copular sentences such as is fear é seo 'this is a man' (Cf. Mahon 1984: 141, 143; 'non verbal sentence' Ó Baoill 2009: 216; Ó Siadhail 1989: 234-235, na mBráithre Críostaí 1999: 202, §16.8).

The construction does show affinities with copular nominal sentences. First, there is the pronoun insertion, typical of copular sentences. Secondly, the presented NP provides identification of an aforementioned element or an entire textual segment, to which $\sin$ itself points. In that sense, $\sin$ constitutes a link between two elements, and the presented element functions as a nominal rheme.

However, since I do find various types of copular sentences in both the dialogue and narrative, such as the construction 'copula + nominal rheme + nominal theme' as in the dialogue line: 'Is $i$ an duine deireannach acu $i$, a Mharcais' 'She is the last one of them, Marcus' (Ó Conaire 1982: 85), I conclude that there is still an opposition of form and function between the various constructions. I also find that the construction in question is typical of presentative constructions, and its narrative functions correlate with the explicative function described for presentational constructions. I therefore classify this construction as presentative. Future research will have to account for this construction in opposition to other nominal copular constructions and examine their distribution and functions.

Another problem posed by the construction is that of the ' $e$, $i$, iad insertion rule' as it was termed by Ó Siadhail (1989: 224). In some examples the pronoun cannot be explained by the rule, i.e., there appears an "unnecessary" pronoun when the rheme is an indefinite noun. In order to account for this irregular use, Mahon (1984: 148) examines various records of $18^{\text {th }}$ and $19^{\text {th }}$ century Irish and concludes:

"in the demonstrative-initial construction, the language has always permitted the use of the pronoun before the rheme (whether definite or indefinite). This was merely a topicalizing function. In the southern dialects, however, this usage was generalized before a definite rheme as a result of the re-analysis outlined above"

13 Mahon also discusses cases in which the rheme is an indefinite noun. 
By "topicalizing", I understand that Mahon refers to the presentative function of inserting into the discourse an entity that may be used as a topic (i.e., a theme). Since the construction was reanalyzed as a copula sentence, in analogy, also the inserted the pronoun comes to appear only before definite rhemes. It may be concluded that if indeed such a diachronic process limiting the usage of such pronouns to definite nouns has occurred, then this process has not yet been completed.

Another issue concerns the functional opposition between sin and ba shin. The reanalysis explanation discussed above also accounts for the usage of forms like $b a$ shin and b'in, as seen in (13) and (14) above. In other words, $\sin$ is resegmented or perceived as is in. Following that, there exists the option of replacing is with $b a$ in order to express an opposition of tense. Copular or not, this is a way Modern Irish has found to express opposition of tense in this construction. I am not referring here merely to the distinction grammars make between $i$ as present tense copula and $b a$ as a past/conditional copula. ${ }^{14}$ There is a question of tempus - of the pragmatic or poetic distinction made by the form in order to signal different textual environments. ${ }^{15}$

The current corpus does not suffice to account for this opposition, since there seems to be a stylistic difference in the usage of the two forms between Ó Conaire and Ó Cadhain. My tentative assumption is that in Ó Cadhain's stories, $\sin$ signals that the comment stems from the narrator, i.e. belongs to the narrator-reader world, while ba shin may be rooted in the story-world and in the character's consciousness.

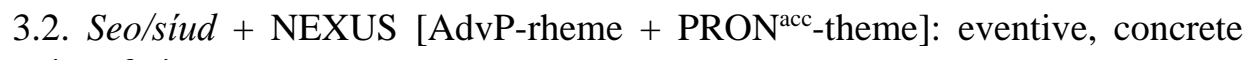
point of view

The presentatives in this section and in Section 3.3 are eventives or eventreporting sentences (Lambrecht 1994: 144). In other words, this kind of nexuspresentation, presents an event into the storyline. Structurally, the presentative element appears first, followed by an AdvP, often indicating movement. Last in the construction is an accusative pronoun.

When an event is presented by seo, it expresses a concrete point of view, i.e. what comes into a character's field of vision. In example (15) the AdvP is the conjugated preposition chugam 'towards=me':

14 As to this formal overlap which may seem unusual from a historical perspective, Wigger (2003: 261) explains that the tense distinction between $b a$ and is is merely an opposition between preterite and non-preterite. However, when $b a$ causes lenition, it is mostly interpreted as a conditional.

15 For the concept of Tempus, see Weinrich (1970, 1971). 
(15) Seo chugam í, agus cosúlacht an aitis ina grua ramhar.

[The king of day is here and so is the fat woman.] Here she [comes] towards me, with the appearance of happiness in her fat cheeks.

(Ó Conaire 1994: 43)

In this example from the novel Deoraiocht, the first-person narrator presents the event of another character approaching him, after her existence in the scene was stated in a preceding clause. This seo presentation expresses subjectivity and a concrete point of view, i.e. representation of visual perception.

In first-person narratives, siud can serve the same function, with the opposition that it signals greater spatial distance from the character-narrator:

(16) siúd trasna na páirce í agus mias mhór ar iompar aici.

[I saw her coming towards me; there she [comes] across the park, carrying a big dish.

(Ó Conaire 1994: 32)

In (17) the rhematic adverbial phrases express both movement and manner. Together they signal the character's heightened emotion and constitute a peak in the scene:

(17) agus nuair nach gcuirfeadh sé cosc lena theangain bhris an gol wirthi agus síud sa seomra go beo í.

[He said a lot of things that will not be told here, which his wife did not like] and when he wouldn't stop talking, she burst out crying and rushed into the room [lit. there in the room quickly her].

(Ó Conaire 1994: 124)

Ó Conaire also makes a comic use of this construction in his first-person narration novel, as a sort of slapstick humour:

(18) Seo chugam i [...], agus siúd ina suí d'aon phlap le mo thaobh í. Here she is coming towards me $[. .$.$] and there she is sitting down with$ a flap next to me.

(Ó Conaire 1994: 43)

In example (19) the construction is used as the dramatic peak of this narrative passage. It also seems to function here like a cinematic swish pan - a swish of the camera, used to follow a subject as it moves across a location (Mercado 2010: 131): 
(19) Siúd ar aghaidh mé ar mo láimh agus ar mo leathghlúin.

[When I was only ten yards from the gate, I thought that I had struck the ground with the crutch forty-three times. I had only four strokes left. But I couldn't do it. I almost started crying but I remembered a trick. I threw the crutch away.] There I go ahead on one hand and one knee. [I had reached the gate having only touched the ground with it forty-three times.]

(Ó Conaire 1994: 71-72)

\subsection{Siúd + NEXUS [AdvP-rheme + PRON ${ }^{\text {acc }}$-theme]}

In contrast to seo and siúd presentation in first-person narration, in third-person narration, only siúd is possible and there is no concrete point of view representation. The nexus appears after the presentative element siúd and features a rhematic AdvP followed by an accusative pronoun representing the thematic entity.

Note that more than one AdvP is possible. In (20) we find in the first sentence two adverbial phrases: anonn 'across' and trasna an urláir 'across the floor'. In the second sentence, we find anall 'back' and arís 'again':

(20) D'éirigh an seanfhear de gheit. Siúd anonn trasna an urláir é. Siúd anall arís é.

The old man got up with a fright. There he goes up across the floor. There he comes back again. [Lit: Yonder over across the floor him. Yonder hither again him.]

(Ó Conaire 1982: 124)

This eventive nexus-presentation appears within plot-line concatenations. Plotline concatenations are usually a string of preterite verb forms (in some stories or stories' sections the present tense is used instead). Such chains express "normal"-flowing story time. With the siúd presentation construction, the narrator breaks the ongoing chain of events. This delimitation changes the story's rhythm and creates "the sudden effect" or "interruptive" function, as Sasse (2006) referred to it.

In example (21), the construction appears twice, and this amplifies the sense of speed and drama. It is as if suddenly a sports commentator excitedly reports the ongoing events or as if time is speeded-up and put on fast-forward:

(21) Thug an Búrcach léim den chlaí, rug ar a scáth fearthainne agus siúd soir an bóthar é faoi lán tseoil. Siúd thar an droichead é agus fuadar mór faoi, agus iabh ní dheachaigh air go raibh sé ag an dug. 
Burke took a leap from the fence, seized on an umbrella and there he goes eastwards on the road under full sail. There he goes over the bridge in a great rush, and he did not stop until he was at the dock.

(Ó Conaire 1982: 120)

\section{Perception and Cognition verbal forms}

In the corpus, I noticed constructions that share similarities with those shown so far, featuring another type of presentative element. I am talking about certain forms of perception verbs, especially those pertaining to seeing and hearing: impersonal preterite forms, e.g., feiceadh 'was seen' (Section 4.1), conditional second person singular forms, e.g., d'fheicfeá 'you'd see' (Section 4.2), and third person conditional forms, e.g., d'fheicfidis 'they would see', accompanied by a generic agent, such as daoine 'people' (Section 4.3).

A verb of seeing as a presentative element is not unusual. Consider for example French voilà, which is originally the imperative vois là 'see there' (Rabatel 2001: 141) as the fact that the deictic-presentative elements seo/sin/siúd discussed above are also said to stem from a form such as acso, which can be interpreted like the French voici (< vois ici) (Ó Siadhail 1989: 234). In Old Irish, the dependent form of the substantive verb fil is originally the imperative 'see!' of the Celtic root *wel (apparent in Middle Welsh forms as gwelet 'to see'). In archaic and poetic texts, in relative clauses, fil(e) 'who/which is' is attested independently also with an object/accusative pronoun used proleptically, in forms like fil-us 'they are, les voilà' (McCone 1987: 8, Thurneysn 1980: 479). ${ }^{16}$

The connection to point of view is clear in the case of concrete perceptual presentation (the object of seeing being the presentate) but also when the presentation is more abstract and represents scene-setting information.

Structurally, this construction also presents a nexus. Following the perception verb appears a NP representing an entity, which is a story participant or an inanimate object. When pronominal, the pronoun is accusative. Last appears an AdvP, which represents the situation or activity the entity is involved in or its location. Table 2 demonstrates the general construction involving perception verbs as presentative elements.

16 I would like to thank the anonymous reviewer for refering me to McCone on this subject. My gratitude also to Elliot Lash for answering questions on the topic and to Erich Poppe for further references. As he notes, it is accepted also in Welsh that llyma/llyna stem from such formations: syll yma/yna 'look here/there' (Evans 2006: 246 comparing llyma to the French voici). See also Shisha-Halevy (1999: 220-225) and Sturzer (2001) on Middle Welsh patterns with llyma/llyna. 
Informationally, while in the cases of nexus-presentation with seo or siúd the NP was pronominal and known from the context, in this type of nexuspresentation, the NP is usually a noun, not always known from the context, or a character known to the reader but seen through eyes of a passer-by, who does not know the character. In this sense, the NP is much less thematic. It is thematic in relation to the adverbial rheme with which it forms a nexus. When the entity is not known at all, there can be an all-new reading of the constituents. The functions signalled by the construction are the same regardless of the levels of thematicity and rhematicity.

Table 2 'Perception verb $+\mathrm{NP}+$ AdvP'

\begin{tabular}{|c|c|c|}
\hline Presentative element & \multicolumn{2}{|c|}{ Presented element } \\
\hline Perception verb & $\begin{array}{l}\text { NP } \\
\text { entity }\end{array}$ & $\begin{array}{l}\text { AdvP } \\
\text { activity, situation, } \\
\text { location }\end{array}$ \\
\hline $\begin{array}{l}\mathrm{V}^{\mathrm{IMPS}} \text { (tense matches the environement) } \\
\text { Cluineadh, feictear } \\
\text { 'was heard', 'is seen' }\end{array}$ & \multirow{3}{*}{$\begin{array}{c}\text { fear } \\
\text { 'man' } \\
\text { dhá scáil } \\
\text { 'two } \\
\text { shadows' }\end{array}$} & $\begin{array}{l}\text { ag labhairt } \\
\text { 'talking' }\end{array}$ \\
\hline $\begin{array}{l}\text { COND.2SG } \\
\text { d'fheicfeá } \\
\text { 'you'd see' }\end{array}$ & & $\begin{array}{c}\text { agus é ag rith, } \\
\text { 'and him running' }\end{array}$ \\
\hline $\begin{array}{l}\mathrm{V}^{\mathrm{COND} .3 \mathrm{PL}}+\text { generic agent } \\
\text { Daoine ... d'fheicfidis } \\
\text { 'People [passing by], they'd see' }\end{array}$ & & $\begin{array}{l}\text { ar an mballa bán } \\
\text { 'on the white wall' }\end{array}$ \\
\hline
\end{tabular}

\section{1. $\mathrm{V}^{\mathrm{IMPS}}$}

The tense of the impersonal verbal form matches that of the plot line events. Because of this, the impersonal verb form seems to take a part in plot concatenation, but it in fact sets the scene or provides a narrator's comment, introducing into the narrative a sight or a sound, as in example (22):

(22) Cluineadh fear an tí ag labhairt go borb. The husband was heard, talking angrily.

(Ó Conaire 1982: 60)

Example (23) appears in a short story's coda narrated in the present tense, as is typical of codas in Ó Conaire's stories. The impersonal form feictear 'they see, is seen' is therefore also in the present tense: 
(23) Feictear Neill ag an bhfuinneoig fós, an cat mór dubh ar a gualainn aici agus boladh an mhusc ina sróin.

Nell is still seen at the window, the big black cat on her shoulder, and the perfume of musk in her nose.

(Ó Conaire 1982: 117-118)

\section{2. $\mathrm{V}^{\mathrm{COND} .2 \mathrm{SG}}$}

In Ó Conaire's writing, second person singular conditional forms of perception verbs are also used. They are found in first-person narration as well as in thirdperson narration, which fits the nature of Ó Conaire's involved and perceptible narrator:

(24) Ní raibh sa seomra ach coinneal, agus d'fheicfeá dhá scáil ar an mballa bán

There was nothing in the room but a candle and you could see two shadows on the white wall

(Ó Conaire 1982: 114)

(25) Ach má bhí an chathair féin i bhfolach chloisfeá fuaimeanna na cathrach.

But even if the city was hidden, you would hear the sounds of the city.

(Ó Conaire 1994: 15)

As with the deictic-presentatives $\operatorname{seo} / \sin /$ siud , here as well, the deixis $-2^{\text {nd }}$ person sg. - has to do with the narrator's making contact with the reader. I assume that this strategy originates in irrealis conditional sentences of the sort 'if you were there, you would have seen/heard/thought ...'. Example (26) demonstrates such a conditional sentence, in which the apodosis is nexuspresentation, introducing an entity and its location, setting the closing scene of a story:

(26) An oíche úd ar imigh Nóra d'fheicfeá seanfhear istigh i mbád iascaireachta dá mbeifeá ar chéibh Ros Dhá Loch.

The night Nóra left, you would see an old man inside a fishing boat if you were at the pier of Ros Dhá Loch.

(Ó Conaire 1982: 97)

This use of a conditional sentence can be seen as a narrative device to highlight information, by marking it as a comment or a focus. It has already been claimed that in conditional sentences the protasis functions as Topic (Haiman 1978), 
acting as a springboard to the rhematic or focal apodosis (Eshel 2015: §3.2.7 on focussing conditional sentences in Modern Irish).

At the same time, by using a deictic form such as the $2^{\text {nd }}$ person singular, the narrator reaches out to the reader, as if pulling her into the scene, while making himself more perceptible and overt. Even when there is no "if you were there" protasis, the effect remains.

\section{3. $\mathrm{V}^{\mathrm{COND} .3 \mathrm{PL}}+$ generic topic presentation}

The third person plural conditional form of a perception verb with a generic topic, like daoine 'people', shows a similar function to the one discussed in the preceding section. This kind of presentation often occurs in extrapositions as in (27a) or in conditional sentences as in (27b):

(27) a Daoine a mbeadh orthu dul síos ar an gcé go moch ar maidin, d'fheicfidís beirt fhear istigh i ngarraí - seanfhear agus uaireadóir ina láimh aige, agus fear óg [...] agus é ag rith [...].

People who had to go down the quay early in the morning, they would see two men in the field - an old man with a watch in his hand, and a young man running [...].

b Agus dá bhfanfaidis ag féachaint air, d'fheicfidís ag caitheamh léime é agus an seanfhear á tomhas dó.

And if they kept on looking at him, they would see him jumping and the old man measuring it for him.

(Ó Conaire 2008: 59-60)

Similarly to the description above regarding conditional sentence as narrative devices, when the $3^{\text {rd }}$ person form is used, the same strategy takes place, presenting the information following the perception verb in the apodosis clause. In contrast, the narrator is not as apparent in this case, but lets us construct the scene through the point of view of by-passers.

\section{4. $\mathrm{V}^{\mathrm{COND} .2 \mathrm{SG}}$ Cognition verb presentation: narrator's comment}

More abstractly, the narrator uses a similar strategy with cognition verbs in order to comment on a character or on a state of events. In this way, he provides the reader with a subjective evaluative comment.

This construction demonstrates that presentation does not concern only concrete images or sounds but also impressions. With cognition verbs like shilfeá and cheapfá 'you'd think', this pattern functions macro-syntactically as a Comment on a previous Topic or clause, commenting on the impression given off by a character's behaviour or appearance, or commenting on a plot-event: 
(28) Shilfeá ar chaint Áine gur chreid sí féin go raibh an fear dá dtug sí gean beo.

From Áine's words, you'd think she herself believed that the man she gave her love to was still alive.

(Ó Conaire 1982: 37)

This type of presentation is found in Ó Conaire's writing, which tends to have a subjective involved narrator:

(29) Bhí an oíche ag titim nuair a tháinig sé, agus shilfeá go raibh eagla air go bhfeicfí é.

Night was falling when he came, and you'd think he was afraid to be seen.

(Ó Conaire 1982: 110)

In (30), there is also a conditional relationship of the type "when/if you saw her, you'd think" in which the presentative construction appears in the apodosis:

(30) Ní raibh an ógbhean thar ocht mbliana déag d'aois de réir cosúlachta, ach cheapfá nuair d'fheicfeá a lorg i gclábar na sráide gur páiste dhá bhlian déag chuaigh an bealach le chomh beag is bhí a troithe.

The young woman was not more than eighteen years of age by appearance, but when you'd see her footprints in the street's mud, you'd think that it was a twelve years old child who walked this way because her feet were so small.

(Ó Conaire 1982: 119)

The conditional verbal form may also be negative, indicating what impression you would not have:

(31) Is beag solas bhí san áit, ach dá mbeadh solas na gréine féin ann ní shilfeá gur easpag an strainséara seo bhuail isteach sa teach ósta.

It is only little light that was in the place, but even if the there were sunlight there, you wouldn't think that this stranger who walked into the pub was a bishop.

(Ó Conaire 1982: 77)

Verba dicendi also interchange with verbs of cognition:

(32) Bhuail an fear beag bui faoi ar an stól le m'ais. Déarfá go raibh sé lánsásta leis féin agus leis an saol. 
Little Yellow Man set himself down on the stool next to me. You'd say that he was well pleased with himself and with life.

(Ó Conaire 1994: 21)

\section{Summary}

In this article, I have surveyed two types of presentative constructions, distinguished into further sub-types, as reflected by a corpus of literary texts consisting of works by Pádraic Ó Conaire with reference to Máirtín Ó Cadhain. Table 3 summarizes the constructions surveyed in this article along with their functions. Being that the corpus represents narrative and not dialogues, presentation of a nexus is much more abundant than presentation of an NP alone.

The first type of presentative construction examined in Section 3 opens with one of the deictic-presentative elements seo 'here', sin 'there' or siúd 'yonder'. ' $\mathrm{Sin}+\mathrm{NP}$ ' is a construction performing textual presentation, functioning as a narrator's or character's explicating comment. 'Siúd + NEXUS', on the other hand, concatenates with plot-line events and functions as a sudden effect event, spicing the plot with speed and drama. 'Seo + NEXUS' is somewhat similar but found only in first-person narration, representing the character-narrator's visual perception of an event occurring in front of his eyes, mostly that of another character approaching him.

The second type of presentative construction examined in Section 4 features various forms of perception and cognition verbs as a presentative element. The general construction 'perception verb + NEXUS' is used to set the scene in varying degrees of narrator's subjectivity. With the construction 'cognition verb + content clause', the narrator provides the reader with an abstract impression.

In the examined narrative literary corpus examined, presentative constructions preform several functions: expression of a point of view, either the narrator's or that of a character, scene-setting, explication, and signalling boundaries in the text in varying degrees of cohesion and delimitation. The latter is also used to 'sudden effect', adding drama and speeding up story time.

Table 3 Narrative presentative constructions: summary

\begin{tabular}{|l|c|c|c|}
\hline $\begin{array}{l}\text { (1) Presenting } \\
\text { element }\end{array}$ & \multicolumn{2}{|c|}{ (2) Presented element(s) } & Function \\
\hline $\begin{array}{l}\text { DEICTIC- } \\
\text { PRESENTATIVE }\end{array}$ & \multicolumn{2}{|c|}{ NP } & \\
\hline $\sin$ & \multicolumn{2}{|c|}{ NP, nominalizations } & $\begin{array}{c}\text { Textual deixis: narrator's } \\
\text { interpretation and orientation }\end{array}$ \\
\hline siúd & Movement & PRON & Sudden effect (plot, dramatic, \\
\hline
\end{tabular}




\begin{tabular}{|c|c|c|c|}
\hline & \multirow[t]{2}{*}{$\begin{array}{l}\text { AdvP } \\
\text { Rheme }\end{array}$} & \multirow[t]{2}{*}{ Theme } & $\begin{array}{l}\text { humoristic), third-person } \\
\text { narration }\end{array}$ \\
\hline seo & & & $\begin{array}{l}\text { Event in the first-person } \\
\text { narrator's field of vision }\end{array}$ \\
\hline $\begin{array}{l}\text { PRESENTATIVE } \\
\text { ELEMENT }\end{array}$ & \multicolumn{2}{|c|}{ NEXUS } & NEXUS PRESENTATION \\
\hline $\begin{array}{l}\text { PERCEPTION } \\
\text { VERB: }\end{array}$ & \multirow{4}{*}{$\begin{array}{l}\text { NP } \\
\text { Theme }\end{array}$} & \multirow{4}{*}{$\begin{array}{l}\text { AdvP } \\
\text { Rheme }\end{array}$} & Scene-setting \\
\hline $\begin{array}{l}\mathrm{V}^{\mathrm{IMPS}} \text { (tense matches } \\
\text { environment) }\end{array}$ & & & $\begin{array}{c}\text { Object of perception, objective } \\
\text { mise-en-scene }\end{array}$ \\
\hline $\mathrm{V}^{\mathrm{COND} .2 \mathrm{SG}}$ & & & $\begin{array}{l}\text { Narrator brings addressee into } \\
\text { the scene }\end{array}$ \\
\hline $\begin{array}{l}\mathrm{V}^{\mathrm{COND} .3 \mathrm{PL}}+\text { generic } \\
\text { agent }\end{array}$ & & & $\begin{array}{c}\text { Scene-setting, narrator's } \\
\text { footprints }\end{array}$ \\
\hline $\begin{array}{l}\text { COGNITION VERB: } \\
\text { V COND.2SG }\end{array}$ & \multicolumn{2}{|c|}{$\begin{array}{l}\text { Content clause } \\
\text { go- / ná }\end{array}$} & $\begin{array}{l}\text { Narrator's comment: } \\
\text { impression }\end{array}$ \\
\hline
\end{tabular}

\footnotetext{
Abbreviations

AdvP adverbial phrase

COND conditional

$F$ feminine

IMPS impersonal

$M$ masculine

NP noun phrase

PL plural

PN proper name

PRON pronoun

SG singular
}

\section{REFERENCES}

\section{PRIMARY SOURCES}

An t'Ádh: Ó Conaire, Pádraic (2008: 77-84) [1907]. Short story.

An Bhean ar Leag Dia Lámh Uirthi: Ó Conaire, Pádraic (1982: 52-65). Short story.

Anam an Easpaig: Ó Conaire, Pádraic (1982: 66-83) [1918]. Short story.

Beirt Bhan Misniúil: Ó Conaire, Pádraic (1982: 27-43) [1918]. Short story.

An Bhean a Ciapadh: Ó Conaire, Pádraic (1982: 119-132) [1913]. Short story. 
Ceol an Uafáis: Ó Conaire, Pádraic (2008: 33-36) [1925]. Short story.

Ciumhais an Chriathraigh: Ó Cadhain, Máirtín (2006: 11-33). Short story.

Deoraiocht: Ó Conaire, Pádraic (1994) [1910]. Novel.

Na Gaiscígh: Ó Conaire, Pádraic (2008: 53-76) [1908]. Short story.

Ná Lig Sinn i gCathú: Ó Conaire, Pádraic (1982: 44-51) [1911]. Short story.

M'Asal Beag Dubh: Ó Conaire, Pádraic (2008: 23-28) [1917]. Short story.

Nóra Mharcais Bhig: Ó Conaire, Pádraic (1982: 84-97) [1907]. Short story.

Neill: Ó Conaire, Pádraic (1982: 98-118) [1908]. Short story.

Páidin Mháire: Ó Conaire, Pádraic (1982: 133-145) [1908]. Short story.

An Strainséara: Ó Cadhain, Máirtín (2006: 61-121). Novella.

\section{SECONDARY SOURCES}

na mBráithre Críostaí. 1999 [1960]. Graiméar Gaeilge na mBráithre Críostaí. Baile Átha Cliath: An Gúm

Cohen, Eran. 2008. The Copular Clause in Jewish Zakho Neo-Aramaic. Journal of semitic studies, 53(1). 43-68.

Cohen, Eran. 2014. Presentatives in comparative view: Biblical Hebrew and Neo-Aramaic. In Tal Davidovich, Ablahad Lahdo \& Torkel Lindquist (eds.), From Tur Abdin to Hadramawt. Semitic Studies Festschrift in Honour of Bo Isaksson on the occasion of his retirement, edited by, 23-38. Wiesbaden: Harrassowitz.

Cohen, Eran. 2016. The European structuralist language description method. Proceedings of the conference The Cours de Linguistique Générale revisited: 1916-2016. Polis Institute, Jerusalem, March 31 and April 1, 2016.

Eshel, Orit. 2015. Narrative grammar and narrative modes. Jerusalem: Hebrew University of Jerusalem dissertation.

Eshel, Orit. Submitted. Presentational cleft constructions in literary Modern Irish.

Evans, Simon D. 2006 [1964]. A Grammar of Middle Welsh. Dublin: DIAS.

Gast, Volker and Florian Haas. 2011. On the distribution of subject properties in formulaic presentationals of Germanic and Romance: A diachronic-typological approach. In Andrej Malchukov and Anna Siewierska (eds.), Impersonal constructions: a crosslinguistic perspective, 127-165. Amsterdam / Philadelphia: John Benjamins Publishing Company.

Haiman, John. 1978. Conditionals are topics. Language. 564-589.

Lambrecht, Knud. 1994. Information structure and sentence form: Topic, focus, and the mental representations of discourse referents. Vol. 71. Cambridge: Cambridge University Press.

Lambrecht, Knud. 2000. When subjects behave like objects: An analysis of the merging of S and $\mathrm{O}$ in sentence-focus constructions across languages. Studies in Language 24(3). 611682.

Mac Cana, Proinsias. 1973. On Celtic word order and the Welsh 'abnormal' sentence. Ériu 24. 90-120.

Mahon, William J. 1984. Some Notes on the Demonstrative-Initial Construction. In Paul Jefferis and William J. Mahon (eds.). Proceedings of the Harvard Celtic Colloquium 4. Dept. of Celtic Languages and Literatures, Faculty of Arts and Sciences, Harvard University. 141-148. 
Mercado, Gustavo. 2010. The Filmmaker's Eye: Learning (and Breaking) the Rules of Cinematic Composition. New York and London: Focal Press.

Ó Baoill, Dónall. 2009. Irish. In Martin Ball and Nicole Muller (eds.), The Celtic Languages, 2nd Edition, 163-229. London and New York: Routledge

Ó Cadhain, Máirtín. 2006. Dhá scéal / Two Stories. Translated by Louis de Paor, Mike McCormack and Lochlainn O Tuairisg. Galway: Arlen House.

Ó Conaire, Pádraic. 1994 [1910]. Deoraiocht. Baile Átha Cliath: An Comhlacht Oideachais.

Ó Conaire, Pádraic. 2008. Rogha Scéalta. Edited by Diarmuid de Faoite. Conamara: Cló IarChonnachta.

Ó Conaire, Pádraic. 1982. Scothscéalta. Baile Átha Cliath: Sáirséal - Ó Marcaigh.

Ó Siadhail, Mícheál. 1989. Modern Irish: Grammatical Structure and Dialectal Variation. Cambridge: Cambridge University Press.

Sasse, Hans-Jürgen. 1987. The thetic/categorical distinction revisited. Linguistics 25(3). 511-580.

Sasse, Hans-Jürgen. 2006. Theticity. In Giuliano Bernini and Marcia L. Schwartz (eds.), Pragmatic organization of discourse in the languages of Europe. (Empirical Approaches to Language Typology) 20(8), 255-310. Berlin: Walter de Gruyter.

Shisha-Halevy, Ariel. 1995. Structural Sketches of Middle Welsh Syntax (I): The Converter Systems. Studia Celtica 29: 127-223.

Shisha-Halevy, Ariel. 1998. Structural studies in modern Welsh syntax: aspects of the grammar of Kate Roberts (Studien und Texte zur Keltologie 2). Münster: Nodus.

Shisha-Halevy, Ariel. 1999. Structural Sketches of Middle Welsh Syntax (II): Noun Predication Patterns. Studia Celtica 33. 155-234.

Shisha-Halevy, Ariel. 2003a. Celtic Syntax, Egyptian-Coptic Syntax. In Monika Hasitzka, Johannes Diethart \& Günther Dembski (eds.), Das Alte Ägypten und seine Nachbarn: Festschrift Helmut Satzinger, 245-302. Krems: Österreichisches Literaturforum.

Shisha-Halevy, Ariel. 2003b. Juncture Features in Literary Modern Welsh: Cohesion and Delimitation - Problematik, Typology of Exponents and Features. Zeitschrift $f$ Celtische Philologie 53. 230-258.

Shisha-Halevy, Ariel. 2016. Work Notes on Modern Welsh Narrative Syntax (II): Presentatives in Narrative. Journal of Celtic Linguistics 17(1). 97-146.

Sturzer, Ned. 2001. How Middle Welsh Expresses the Unexpected. Cambrian Medieval Celtic Studies 41. 37-53.

Rabatel, Alain. 2001. Valeurs énonciative et représentative des 'présentatifs' C'EST, IL YA, VOICI/VOILA: effet point de vue et argumentativité indirecte du récit. Revue de sémantique et pragmatique 9-10. 43-74.

Ribera, Josep. 2007. Text deixis in narrative sequences. International Journal of English Studies 7.1. 149-168.

Thurneysen, Rudolf. 1946. A grammar of Old Irish (Vol. 1). Dublin: DIAS.

Weinrich, Harald. 1970. Tense and Time. Archivum Linguisticum, n.s. 1. 31-41.

Weinrich, Harald. 1971 [1964]. Tempus - Besprochene une erzälter Welt. Stuttgart Berlin Köln Mainz: W. Kohlhammer.

Wigger, Arndt. 2003. Irisch. In Thorsten Roelcke (ed.), Variationstypologie-ein sprachtypologisches Handbuch der europäischen Sprachen in Geschichte und Gegenwart, 251-276. Berlin: de Gruyter. 


\section{List of tables}

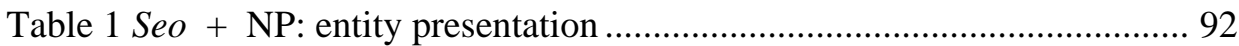

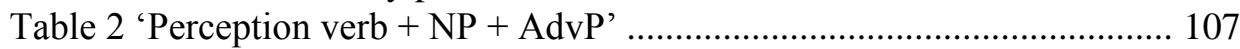

Table 3 Narrative presentative constructions: summary ................................. 111 